http://dx.doi.org/10.4314/jae.v17i1.9

\title{
Training Needs of Pineapple Farmers in Enugu State, Nigeria
}

\author{
Iwuchukwu J.C, Udoye C. E. and Onwubuya E.A. \\ Department of Agricultural Extension, \\ University of Nigeria Nsukka, Enugu State, Nigeria. \\ E-mail julieiwuchukwu@yahoo.com (08063276459)
}

\begin{abstract}
The study identified training needs of pineapple farmers in Enugu State, Nigeria. Purposive sampling technique was used to select two zones (Awgu and Nsukka zones), four blocks, eight circles and eighty pineapple farmers that were used for the study. Some of the data were analysed with percentage and mean score while some were presented in charts.. Majority (77.5\%) of the respondents did not have contact with extension agents in 2011 and they sourced information on pineapple from neighbours (86.3\%). The mean annual expenditure and income from pineapple were $\mathrm{A} 27,568$ and $\mathrm{A} 235,530$ respectively. Majority (96.2\%) of the respondents had no training on processing and preservation of pineapple and off season production of pineapple (85\%). Majority of the respondents indicated that training on pineapple should be organized by researchers (65\%) through interpersonal communication (83.8\%) using local language (Igbo) (78.8\%). Provision of effective micro-credit facilities $(M=2.84)$ and stability of government policy (stability of price of pineapple) $(M=2.68)$ were perceived by the respondents as major strategies that will improve pineapple production in the area. The study encouraged building capacities of pineapple farmers through informal training especially in the areas of processing, preservation and off-season production of pineapple so that they can face challenges of the enterprise, boost their farm size and income.
\end{abstract}

\section{Key words: Training needs Pineapple Farmers Enugu State}

\section{Introduction}

Pineapple is a tropical fruit. It is also a delicious fruit that is eaten fresh, canned or juiced. Until recently, about $80 \%$ of pineapple produced in Nigeria came from small scale farms managed under mixed cropping systems (Fawole,2008). Current production figures show that Nigeria is the 6th largest producer of pineapple in the world and if current production and marketing trends are encouraged, commercial production for export and consumption will be enhanced (FAO/World Bank, 1999 in Fawole, 2008). Pineapple current production in Nigeria is about 17,000metric tons per annum (Onwualu, nd). According to the author, Nigeria can produce 364,490 metric tons of pineapple per annum if its production challenges are properly addressed.

The popularity of pineapple is due to its sweet-sour taste containing $15 \%$ sugar, malic and citric fruit acids. It is also high in vitamin B1, B2, B6 and C. Its protein digesting enzyme, bromelain seems to help digestion at the end of a heavy protein meal (Nwosu, 2011). Pineapple is an excellent cerebral toner; it combats loss of memory, sadness and melancholy (Joy, 2013). Pineapple has many by products that are very much needed by the people. It can be made into jam, juice, vinegar and 
other different food types. It can also be made and processed into a high quality cloth. Its covering and other waste coming from canning may be used as livestock feeds. Pineapple is therefore an economic crop that has encouraging potentials for foreign exchange earnings (Fawole, 2008).

Today's work environment and problems require that workers be skilled in performing complex tasks in an efficient, cost-effective, and safe manner. Similarly, for agriculture to become sustainable, it needs more cohesion, stronger voice and more than ever, skilled, active, proactive and visionary farmers that will address key issues that affect the sector. Also, enhancing agricultural production in Nigeria is often linked to farmers' access and use of agricultural information (Fawole, 2008). Farmers can adopt/use these information well when they have been properly trained on how to apply them.

Training by nature, is an organized activity aimed at imparting information and/or instructions to improve the recipients performance or to help him or her attain a required level of knowledge or skill (New business dictionary.com). Hence it is an activity leading to skilled behaviour (Compare infobase Limited (nd)) and a performance improvement tool. Since, it is counter-productive to offer training to individuals who do not need it or to offer the wrong kind of training (HR Guide 2012), successful training needs analysis identifies those who need training and what kind of training is needed thereby putting training resources to good use and enhancing productivity.

Given the importance of pineapple and the possibility of exceeding current production estimates in Nigeria, it becomes pertinent to identify training needs of pineapple farmers which will serve as critical factors that needs to be addressed in other to ameliorate challenges and hence realize potentials of the fruit. In view of the aforementioned facts, the study assessed training needs of pineapple farmers in Enugu State, Nigeria. Specifically, the study examined characteristics of pineapple farmers in the study area, sources of information, areas of training and strategies for enhancing pineapple production in the area.

\section{Methodology}

The study was carried out in Enugu state, Nigeria. The state has seventeen Local Government Areas and six agricultural zones. Pineapple farmers in the state constituted the population for the study. A multi-stage sampling technique was used in the selection of the respondents. From the six agricultural zones, two (2) zones; (Awgu and Nsukka) were purposively selected because of their high involvement in pineapple production. Two (2) blocks were also purposively selected from each of the selected zones because of the same reason given above. This gives a total of four (4) blocks for the study. From each of the selected blocks, Two circles where pineapple farmers dominate were also purposively selected from each of the selected blocks giving a total of eight (8) circles for the study. Ten pineapple farmers were purposively selected from each of the circles giving a total of eighty (80) respondents for the study.

Data were collected from the respondents through the use of structured interview schedule. It contained relevant questions based on the objectives of the study. 
Respondents were asked to indicate the number and types of organization(s) they belong to, their sources of information on pineapple production, number of extension contact in 2011, total income and expenditure on pineapple production in one season (2011).

Farmers were asked to tick from the list provided areas they had training on pineapple production. Some areas indicated in the list were irrigation, fertilizer application, pest and disease control etc. They were also asked to indicate who they will want to organize training for them, resource person, method and language that they will want to be used in training them. List of perceived enhancing factors was provided in a three (3) point Likert-type scale with responses as; to a great extent (3), to a little extent (2), and to no extent (1) with a mean of 2.0 in other to ascertain strategies for enhancing pineapple production in the area. Any variable with a mean score higher or equal to 2.0 was regarded as a major strategy while variable with a mean score less than 2.0 was regarded otherwise. Some of the data were analysed with percentage and mean score while some were presented in charts. These analyses were executed with the help of Statistical Product and Service Solution (SPSS) version 16.

\section{Results and discussions}

\section{Membership of social organization}

Table 1 reveals that $93.8 \%$ of the respondents belonged to social organizations. Among respondents that belonged to social organizations, $73.8 \%$ were members of religious group, $25 \%$ of them belonged to farmers group while $20 \%$ and $8.8 \%$ of them belonged to cooperative and political organizations, respectively. Involvement of farmers in social organizations especially farmers group and cooperative could enhance diffusion of information and reception of government assistance in form of loans, subsidies and other inputs.

\section{Agricultural extension contact}

Table 1 reveals that $77.5 \%$ of respondents didn't have contact with extension agents in 2011 while $22.5 \%$ had contact with extension agents. This finding is in line with what is happening in most developing countries like Nigeria where farmer-extension contact is almost non-existent probably due to poor remuneration and logistical problems. 
Table 1

Distribution of the respondents according to their social characteristics

\begin{tabular}{ll}
\hline Variables & Percentage $(\mathbf{n}=\mathbf{8 0})$ \\
\hline Membership of social organization & \\
No & 6.2 \\
Yes & 93.8 \\
*Social organization(s) belonged to & 6.2 \\
None & 25 \\
Farmers group & 73.8 \\
Religious group & 20 \\
Cooperative society & 8.8 \\
Political group & \\
Contact with extension agents in 2011 & 22.5 \\
Yes & 77.5 \\
No & \\
\hline
\end{tabular}

${ }^{*}$ Multiple responses Source: Field survey July, 2012

\section{Sources of information on pineapple farming}

Figure 1 reveals that majority (86\%) of the respondents sourced information on pineapple farming from their neighbours. Those that got it from extension agents accounted for $9 \%$ while $8 \%$ and $3 \%$ of the respondents got it from radio and television respectively. It is certain that most of these farmers will not source information on pineapple production from extension agent since most of them lacked extension contact (Table1).When farmers do not have access to formal extension services, they use other sources of information or ask other farmers and their input suppliers (Global Forum for Rural Advisory Services (GFRAS), 2012).

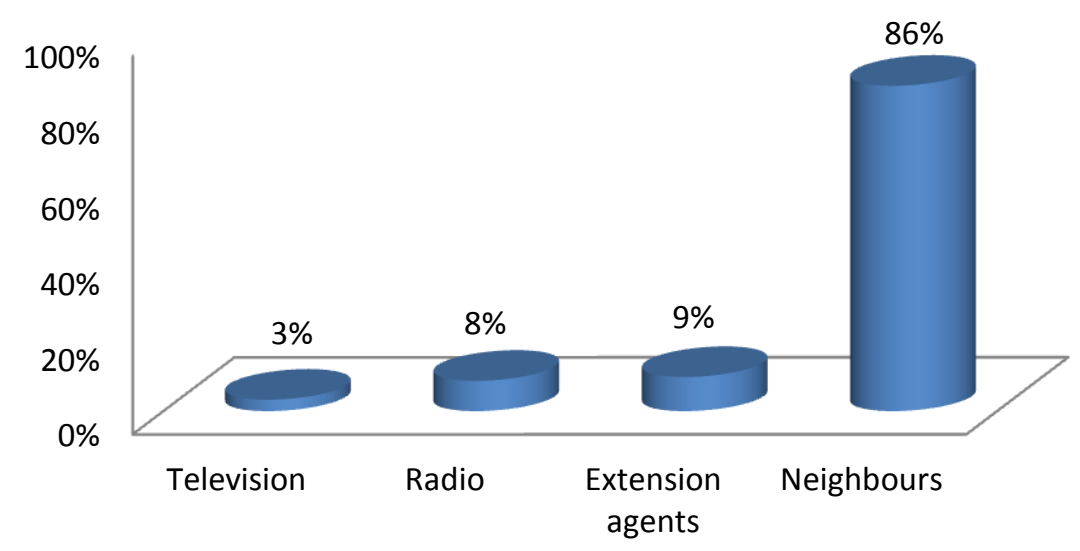

production

Figure 1: Sources of information of the respondents on pineapple 


\section{Journal of Agricultural Extension}

Vol. 17 (1) June, 2013

ISSN 1119-944X

\section{Annual income and expenditure from pineapple production in a season/year}

From Table 2, it can be inferred that $27.5 \%$ of the respondents earned more than N250, 000 from pineapple in a season/year, 21.2\% of the respondents earned between $A 1,0001$ to $\$ 50,000$ while $20 \%$ of them earned between $A 50,001$ to N100,000. The mean annual income of the respondents from pineapple in a season was ${ }_{2} 235,530$.

Entries in Table 2 also show that greater proportion (38.8\%) of the respondents spent between $\$ 1,001$ to $\$ 10,000$ while $13.8 \%$ spent between $\$ 10,001$ to $\$ 20,000$ on pineapple production in a season/year. The mean annual expenditure of the respondents on pineapple production per season was \#27, 568. The finding shows that the farmers spent less and earn high income (Table2) from pineapple indicating that pineapple production is a lucrative business in the area. The finding tend to supports the fact that pineapple production has become the key source of economic growth in Costa Rica (www.rainforest.alliance.org)

Table 2

Distribution of the respondents according to annual income and expenditure on pineapple production $(n=80)$

\begin{tabular}{ccc}
\hline $\begin{array}{l}\text { Variables } \\
\text { Mean }\end{array}$ & percentage & $(\mathrm{n}=80)$ \\
\hline
\end{tabular}

Annual income from pineapple

235,530

No response

5.0

1,001-50,000

21.2

$50,001-100,000$

20.0

100,001-150,000

17.5

$150,001-200,000$

3.8

200,001-250,000

5.0

$>250,000$

27.5

Expenditure on pineapple production

27,568

No response

15.8

1,001-10,000

38.8

$10,001-20,000$

13.8

20,001-30,000

10.0

$30,001-40,000$

3.8

$40,001-50,000$

10.0

$>50,000$

10.0

Source: Field survey July, 2012

\section{Areas respondents had training on pineapple production}

Data in Table 3 show that majority $(81.2 \%)$ of the respondents had no training on suitable site /land for pineapple production while (18.8\%) had training on it. Selection of good site/land for specific agricultural crop is likened to productivity /yield, hence the need for these farmers to be properly trained on ideal site/land for pineapple production. 


\section{Journal of Agricultural Extension}

Vol. 17 (1) June, 2013

ISSN 1119-944X

Majority (71.2\%) of the respondents had no training on soil management and conservation practices while (28.8\%) had training on these practices (Table3). Many people that are engaged in farming report that their livelihood is becoming less viable due to lack of access to farmland, rising land costs, unfavourable agricultural and land tenure policies, population growth, fragmentation of holdings, over use and degradation of cultivated lands (World Bank, 2000). Training related to land/soil will help farmers to manage and conserve this important factor of production.

Table 3 show that majority (61.2\%)) of the respondents had training on identification of good species/varieties of pineapple while (38.8\%) had no training on it. Training of these farmers on the good varieties may invariably motivate them to use them in their production in other to increase output.

As shown in Table 3 , majority $(85.0 \%)$ of the respondents had no training on offseason production of pineapple while $(15.0 \%)$ had training on it. Since majority of these respondents did not undergo training on off-season pineapple production, it is unlikely that they will produce pineapple during off-season which tends to generate more income than main season production.

About $51 \%$ of the respondents had training on pruning techniques while $(48.8 \%)$ had no training on it (Table 3). This shows that greater proportion of the farmers had training on pruning technique which is meant to remove extra suckers from a stand thereby allowing the growing ones to give maximum yield.

Table 3 further reveals that greater proportion (58.8\%) of the respondents had no training on irrigation while the remaining $41.2 \%$ had training on irrigation. Since majority of these farmers did not have training on off-season production, it is likely that they will not have on irrigation which is a supplementary water supply to plants/crop especially during dry/off season

Data in Table 3 show that majority $(61.2 \%)$ of the respondents had training on fertilizer application while (38.8\%) had no training on it. Majority of the respondents may have undergone training on fertilizer application because it is one of the commonest input used by farmers in growing their crops.

Table 3 also shows that majority $(62.5 \%)$ of the respondents had no training on pest and disease control on pineapple while the remaining (37.5\%) had training on it. Training the farmers on how to combat disease and pest infestation in the farm will reduce cost of production as well as increasing the quality of pineapple produced.

Entries in Table 3 show that majority $(81.2 \%)$ of the respondents had no training on pineapple harvesting operation while $(18.8 \%)$ had training on it. This training is pertinent as premature harvest, late harvest, poor method of harvesting etc are detrimental and can lead to heavy losses. Yet most of these farmers were not trained on it.

It is obvious in Table 3 that a greater proportion (96.2\%) of the respondents had no training on processing and preservation of pineapple while $(3.8 \%)$ had training on them. Processing aims at preserving the nutrients in the food in order to make them available to the consumers (Hassal, Osman and Babiker, 2005). Seasonality of 


\section{Journal of Agricultural Extension}

Vol. 17 (1) June, 2013

ISSN 1119-944X

agricultural products like pineapple makes it necessary that farmers be trained on how to process and preserve this product during period they are abundant to reduce losses and ensure year round supply of this product.

From Table 3 it can be seen that majority (66.2\%) of the respondents had no training on record keeping while (33.8\%) had training on it. Farm records and accounts are very important as they help farmers to obtain exact knowledge about present \& potential gross income and operating costs (Agriculture information bank, 2011). These information help them to manage their farms profitably.

Table 3

Areas respondents had training on pineapple production

\begin{tabular}{lc}
\hline Variables & percentage $(\mathbf{n}=\mathbf{8 0})$ \\
\hline & Yes \\
Selection of suitable site/land & 81.2 \\
Soil management and conservation & 28.8 \\
Identification of good species & 61.2 \\
Off season production & 15.0 \\
Pruning technique & 51.2 \\
Irrigation system & 41.2 \\
Fertilizer application & 61.2 \\
Pest and disease control & 62.5 \\
Harvesting operations & 18.8 \\
Processing and preservation & 3.8 \\
Record keeping & 33.8 \\
\hline
\end{tabular}

Source: field survey July, 2012

\section{Organization of the training}

\section{Organizers of the training}

Entries in Table 4 reveal that majority (65\%) of the respondents indicated that they would want research institute to organize training on pineapple for them, $45 \%$ indicated government, $10 \%$ indicated NGOs, while $8.8 \%$ indicated community based organization as outfit that they would want to organize training for them. It is surprising that none of the respondents pointed out extension agency that has the mandate of training farmers on recommended practices. This exposes lapses and inefficiency of extension services in Nigeria probably due to logistic problems which may consequently undermine its contribution and impact on agricultural growth.

\section{Method of conducting training}

Table 4 further reveals that interpersonal communication (83.8\%), workshop $(82.5 \%)$ and demonstration (82.5\%) were indicated by majority of the respondents as methods that will be used in conducting training for them. Being rural farmers who are oftentimes illiterates, they will prefer the aforementioned methods that are participatory and allow physical interactions between the trainer and the trainee with direct feedback thereby enhancing effectiveness of training. 


\section{Trainer/resource person}

Data in Table 4 show that majority (88.8\%) of the respondents indicated that they will prefer researchers to be their trainer/resource person, $26.3 \%$ indicated clergy while $10 \%$ indicated lecturers. Their preference for researchers may be derived from the fact that researchers generate credible information/technology on agriculture and are more likely to transfer it to farmers in an undiluted form.

\section{Language of communication during training}

Data in Table 4 show that majority (78.8\%) of the respondents pointed out local language (Igbo) only; 17.5\% indicated combination of Igbo and English languages while $3.8 \%$ indicated English language only as medium of communication during training. Being rural farmers who usually have poor educational status, they will prefer local language as medium of communication during training.

Table 4

Percentage distribution of respondents on organization of training

\begin{tabular}{lc}
\hline Organization & Percentages $\mathbf{( n = 8 0 )}$ \\
\hline *Organizers of the training & 45 \\
Government & 10 \\
NGO & 65 \\
Researchers & 8.8 \\
Community organization & \\
*Method of conducting training & 13.8 \\
Formal training & \\
Demonstration & \\
$\quad 82.5$ & 82.5 \\
Workshop & 83.8 \\
Interpersonal & 47.5 \\
Mass media & 3.8 \\
Internet & \\
*Trainer/resource person & 3.8 \\
School teachers & 10.0 \\
Lecturers & 88.8 \\
Researchers & \\
Clergy & \\
26.3 & \\
Language & \\
English & \\
Local(Igbo) & 3.8 \\
Both & 78.8 \\
"Multiple responses & 17.5 \\
\hline
\end{tabular}




\section{Strategies for improving pineapple production}

It can be inferred from Table 5 that all the factors in the table were perceived by the respondents as major strategies for improving pineapple production in the area. Some of these major strategies as indicated by the respondents were increased extension contact $(M=2.94)$, investing in pineapple research to solve pineapple farmers problems $(M=2.91)$, labour availability $(M=2.89)$, establishment of effective farmers association to enable them solve their problem together $(M=2.85)$, Provision of good market $(M=2.84)$., provision of effective micro-credit facilities $(M=2.84)$, provision of incentives and subsidies like fertilizers, improved seedlings agrochemicals etc $(M=2.80)$ and construction of road $(M=2.74)$. These findings may be said to agree with current policy directions in agriculture which emphasize on extending public private (including public NGO) partnerships in service and input delivery, strengthening farmers associations and demand for advisory services and tackling gaps and failures in private marketing systems (Ellis, 2004).

Table 5

Mean scores of strategies for improving pineapple production

\begin{tabular}{lll}
\hline Perceived strategies & Mean & SD \\
\hline Provision of effective micro-credit facilities & $2.84^{*}$ & 0.462 \\
Stability of government policy on pineapple enterprise & $2.68^{\star}$ & 0.546 \\
Labour availability & $2.89^{\star}$ & 0.318 \\
Use of organic manure only & $2.41^{*}$ & 0.567 \\
Construction of available road network & $2.74^{*}$ & 0.545 \\
Provision of irrigation systems & $2.34^{\star}$ & 0.635 \\
Establishment of farmers association & $2.85^{\star}$ & 0.453 \\
Involvement of youth in pineapple production & $2.69^{\star}$ & 0.493 \\
Provision of incentives and subsidy & $2.80^{*}$ & 0.488 \\
Investing in pineapple research & $2.91^{*}$ & 0.363 \\
Increase extension contact & $2.94^{\star}$ & 0.244 \\
Provision of good market & $2.84^{*}$ & 0.434 \\
\hline
\end{tabular}

\section{Source: field survey, June 2012}

\section{Conclusion}

Majority of the respondents were members of religious group, lacked extension contact and sourced information on pineapple production from mainly neighbors. Although most of them had no training on specific area of pineapple production, they realized big income from the business. These indicate that pineapple production is a lucrative business.

\section{Recommendations}

Based on the major findings of this work, the following recommendations were made: 1. Research institutes, universities, colleges of agriculture etc should invest in pineapple research to solve pineapple farmer's problems. The research should focus mainly on areas like suitable land/soil for pineapple production, soil conservation and management practices, off-season production, harvesting and processing operations, as well as record keeping. 


\section{Journal of Agricultural Extension}

Vol. 17 (1) June, 2013

ISSN 1119-944X

2 Agricultural extension system should be strengthened by provision of conducive environment for their operations so that output of the research can be transferred by them through training and ultimately utilized by the targeted audience for increased output

3. Government and non-governmental organizations, like community based organisation and even patriotic citizens should embark on development programme and projects in the area. Provision of basic infrastructural facilities such as construction of good market and road network for easy transportation of agricultural produce especially pineapple from the point of production to utilization should be given utmost priority

\section{References}

Agricultural information bank, (2011). Agriinfo.in (C 2011 accessed 02/05/2013

Agricultural Leadership Foundation of Hawaii, ( 2012). The need for leadership: Challenges of agriculture in Hawaii today.

Compare infobase Limited (nd) www.ocx.com.ng accessed 02/05/2013

Ellis, F. (2004). Occupational diversification in developing countries and implications for agricultural policy. Overseas Development Group (ODG), University of East Anglia, Norwich.

Fawole, O.P (2008). Pineapple farmers information sources and usage in Nigeria. Bulgarian Journal of Agricultural Science, 14(4):381-389.

Global Forum for Rural Advisory Services (GFRAS), (2012). Facts sheet on extension services. position paper, June, 2012, www.g.fras.org assessed $27 / 10 / 2012$

Hassal, A.B, Osman,G.A, and Babiker,E.E,(2005). Effects of domestic processing and antinutrients and protein and mineral of lupin (lupinus termis). Journal of Food Technology, 3:263-268.

HR-Guide, (2012). Needs Analysis: how to determine training needs. Copyright 2012, LLC http: //ww.south bound. Com.my/accessed 9/3/08.

Joy, P.P, (2013). Pineapple sector in Kerala: status, opportunities, challenges and stakeholders. Pineapple Research Station (Kerala Agricultural University), Vazhakulam-686 670, Muvattupuzha, Ernakulam, Kerala, India. www.kau.edu/prsvkm

Newbusinessdictionary.com 
Journal of Agricultural Extension

Vol. 17 (1) June, 2013

ISSN 1119-944X

Nwosu, C. (2011). Nigerian guide to pineapple business/cost \& profit analysis. nbf(at)nigerianbestforum.com

Onwualu, (nd) www.freshplaza.com accessed 02/05/2013

World Bank, (2000). Voices Of The Poor: Crying Out For Change. Washington D.C. Oxford University Press.

www.rainforest.alliance.org accessed 02/05/2013 